\title{
Research Article \\ Effect of Piroxicam and/or Ascorbic Acid on Postoperative Pain in Orchidectomised Goats
}

\author{
Richard Oluchukwu Okafor, Bolanle Dupe Remi-Adewunmi, and Samuel Tanko Fadason \\ Department of Surgery and Radiology, Faculty of Veterinary Medicine, Ahmadu Bello University, Zaria 810006, Nigeria \\ Correspondence should be addressed to Richard Oluchukwu Okafor; richiestands@hotmail.com
}

Received 16 January 2014; Revised 24 June 2014; Accepted 21 August 2014; Published 10 September 2014

Academic Editor: Yoshihiro Ohmiya

Copyright (C) 2014 Richard Oluchukwu Okafor et al. This is an open access article distributed under the Creative Commons Attribution License, which permits unrestricted use, distribution, and reproduction in any medium, provided the original work is properly cited.

\begin{abstract}
The study evaluates effects of varied doses of ascorbic acid and piroxicam on behavioural signs of pain in orchidectomised Savannah Brown goats during their postsurgical pain management. The goats were divided into 6 groups of 3 goats each. Orchidectomy was performed on all animals under sedation with xylazine and linear infiltration with lignocaine. After surgery, varied doses of piroxicam (IM) and ascorbic acid (IV) were administered to the goats: Group A = piroxicam, $5 \mathrm{mg} / \mathrm{kg}+$ ascorbic acid, $100 \mathrm{mg} / \mathrm{kg}$; Group B = piroxicam, $5 \mathrm{mg} / \mathrm{kg}$ + ascorbic acid, $200 \mathrm{mg} / \mathrm{kg}$; Group C = piroxicam, $10 \mathrm{mg} / \mathrm{kg}+$ ascorbic acid, $100 \mathrm{mg} / \mathrm{kg}$; Group D = piroxicam, $5 \mathrm{mg} / \mathrm{kg}$; Group E: ascorbic acid, $100 \mathrm{mg} / \mathrm{kg}$ together with antibiotics, procaine penicillin, 20,000 IU $/ \mathrm{kg}+$ streptomycin, $10 \mathrm{mg} / \mathrm{kg}$ (IM); and Group F (control) received only the antibiotics. After surgery, pain intensity was determined in each goat by numerical rating scale. Vocalisation, teeth grinding, rapid and shallow breathing, tail wagging, occasionally bleating, neck extension, and dorsal lip curling were recorded at varying degrees across the experimental groups. The goats in the control group showed the highest degree of behavioural signs of pain. It is concluded that treatment with a combination of piroxicam and ascorbic acid ameliorated pain more than either of the agents in orchidectomised Savannah Brown goats.
\end{abstract}

\section{Introduction}

Pain control for routine management procedures is considered one of the most important welfare priorities in livestock production today [1]. Animals in pain reduce their overall level of activity following surgery [2]. Pain associated with various conditions and procedures in animals may be estimated [3]. Pain assessment in animals may be done by one of three approaches: measurements of general body functioning, such as food and water intake and live-weight gain; physiological responses such as plasma cortisol concentrations; and behaviours such as vocalisations [4]. Morton and Griffiths [5] proposed that the study of behavioural patterns constitutes a substantial part of pain assessment and they attempted to define species-specific signs of behaviour indicating pain. Evaluation of behavioural signs has proven to be reliable indicators of pain [6]. Behavioural responses used for pain assessment in goats include: vocalisation, teeth grinding, rapid and shallow breathing [7], standing and lying repeatedly, tail wagging, occasionally bleating, displaying neck extension, dorsal lip curling, kicking, rolling, and hyperventilation [8]. Numerical rating scale (NRS) is used to rate pain intensity and assess pain distress and the degree of subjective suffering, caused by the pain on a numbered scale, such as the 0 to 10 Numeric Pain Intensity Scale [9]. Piroxicam is a nonsteroidal anti-inflammatory drug (NSAID) of the oxicam class, which is nonselective. It undergoes enterohepatic circulation and is primarily used to treat arthritis and other musculoskeletal conditions [10]. Piroxicam exhibits anti-inflammatory [11], analgesic [12], and antipyretic activities in animal models. The mechanism of action of piroxicam, like any other NSAID, is not completely understood but may be related to prostaglandin synthetase inhibition [13].

Ascorbic acid (AA), otherwise known as vitamin $\mathrm{C}$, is an effective nontoxic and inexpensive antioxidant. One of the most widely accepted functions of AA is that it acts as an antioxidant by interrupting free-radical chain reactions in the body [14] and, thus, significantly decreases the levels of reactive oxygen species in the body $[15,16]$. It has been 
established that AA ameliorates the adverse effects of stressful environmental conditions [17-20] and protects the cells from deleterious effects caused by reactive oxygen species [21], generated in large quantity in stressful situations [13].

Castration has been described as the commonest surgical procedure in both large and small animals [22, 23]. The common methods of castration in food animals include: (1) orchidectomy, which is the removal of the testicles after making an incision into the scrotum; (2) band or ring castration, which is constricting the blood supply to the testicles and scrotum; and (3) Burdizzo castration, which involves crushing of the spermatic cord. According to both the American and Canadian Veterinary Medical Associations (AVMA and CVMA, resp.), the castration methods listed above cause both acute and chronic pain [24, 25]. Measures are, therefore, required to alleviate pain in domestic animals during castration. Prunier et al. [26] has shown that, during pain, reactive oxygen species are generated in large quantity. Antioxidants such as AA may, therefore, be beneficial in pain alleviations during surgical interventions in animals.

The aim of the present study was to evaluate behavioural responses of goats, orchidectomised and administered with piroxicam and AA during postsurgical management of pain.

\section{Methods}

Ethical approval letter for the conduct of this experiment was obtained from the Research Ethics Committee of the Department of Veterinary Surgery and Radiology, Ahmadu Bello University, Zaria, Nigeria. Eighteen (18) six-month- to oneand-half-year-old Savannah Brown goats weighing between 6 and $12 \mathrm{~kg}$ were used. The goats were preconditioned for a period of five weeks, during which an independent assessor studied the behavioural pattern of the goats and afterwards general clinical evaluations were conducted on the animals to determine their base-line data before postoperation evaluation. Goats were given access to feeds (hay, beans husk, and maize offals) and clean water ad libitum. The animals were randomly divided into six (6) experimental groups of three (3) goats each. Castration (orchidectomy) was performed on all the animals.

2.1. Presurgical Preparation, Anaesthesia, and Restraint. Orchidectomy was carried out on the animals randomly. The scrotal area was shaved, scrubbed with soap and water, and disinfected with chlorhexidine. The animals were sedated with $0.05 \mathrm{mg} / \mathrm{kg}$ xylazine (XYL-M2, VMD n.v/s.a-Hoge Mauw 900-B-2370 Arendonk, Belgium) intravenously. Local anaesthesia was achieved through a linear infiltration with $5 \mathrm{~mL}$ of $2 \%$ lidocaine hydrochloride (Liga, SAI Parenteral (P) Ltd., Hyderabad-55, India) subcutaneously into the scrotal sac. The animal was then restrained in dorsal recumbency in a surgical cradle, and the scrotum and the surrounding area were disinfected with chlorhexidine [27]. The probes from the autophysiological parameters monitoring machine (General Meditech Inc., model G3D, Guangdong, China) were attached to the goats; surgical area was then draped for surgery.
2.2. Surgical Procedure. The scrotum was grasped and a horizontal incision was made through the skin and the fascia at the widest part of the scrotum (junction of idle and distal thirds). The entire distal segment of the scrotum was transected and traction was placed on the testes and the skin was pushed proximad. The fascia was separated from the spermatic cords and enclosed in the common tunics with care taken to avoid the proximal regions of the spermatic cords. The spermatic cords were ligated by transfixation suture, using size 2 chromic catgut and the cord transacted distal to the ligatures according to the method described by Simon and Wayne [28]. Cutaneous wounds in goats were dressed using topical antibiotics, OXYTETRACYCLINE aerosol spray, containing Gentian violet + oxytetracycline (Sequent Scientific Ltd., Thane, India). Procaine penicillin, 20,000 IU/kg and streptomycin, $10 \mathrm{mg} / \mathrm{kg}$ (CentreProdih, Aether Centre Biology Co., Ltd., Beijing, China) were administered intramuscularly for five consecutive days after surgery. This group (F) served as the control. The same procedures (Surgery, oxytetracycline spray, procaine penicillin, and streptomycin) were carried out on all the animals in Groups A to F. Administration of the drugs was done by the surgeons after each orchidectomy, after which the goats were taken to the independent assessor, who was blinded to the treatment administered, for assessment.

Goats in group A were given piroxicam (piroxicam) (Laborate Pharmaceutical, E-11 Industrial area, Panipat - 123 103, India) at $5 \mathrm{mg} / \mathrm{kg}$ intramuscularly and vitamin C (ECNUC Injection, Yanzhou Xierkangtai Pharmaceutical Co. Ltd., Yanzhou City, China) at $100 \mathrm{mg} / \mathrm{kg}$ intravenously for five consecutive days postsurgically.

Group B goats were given piroxicam at $5 \mathrm{mg} / \mathrm{kg}$ intramuscularly and ascorbic acid at $200 \mathrm{mg} / \mathrm{kg}$ intravenously for five consecutive days postsurgically.

Goats in group C were given piroxicam at $10 \mathrm{mg} / \mathrm{kg}$ intramuscularly and ascorbic acid at $100 \mathrm{mg} / \mathrm{kg}$ intravenously for five consecutive days postsurgically.

Piroxicam was administered at $5 \mathrm{mg} / \mathrm{kg}$ intramuscularly for five consecutive days postsurgically to goats in group D.

Group E goats were given ascorbic acid at $100 \mathrm{mg} / \mathrm{kg}$ intravenously (IV) for five consecutive days (Table 1).

2.3. Behavioural Responses. The behavioural responses of the animals were observed immediately after surgery, three hours after surgery, and every day for the next five days. The observations were carried out at 09:00 h each day by an independent assessor, who had earlier studied the behavioural patterns of the goats during their preconditioning period for five weeks. The observations included the following behavioural events: vocalization in response to pain, grinding of the teeth, and rapid and shallow breathing. Others were standing and lying repeatedly, wagging of tails, occasionally bleating, displaying neck extension, dorsal lip curling, kicking, and rolling. The events were graded according to the Numerical Rating Scale (NRS) [29] by the independent assessor, who was blinded to what the goats were administered with. The scale was interpreted as follows: 0 represents no pain; numbers 1 to 3 on the scale represent mild pain, 4 to 6 moderate pain, and 7 to 10 severe pain. 
TABLE 1: Experimental grouping of animals.

\begin{tabular}{ll}
\hline Group & Treatment protocol \\
\hline A & $\begin{array}{l}\text { Piroxicam at } 5 \mathrm{mg} / \mathrm{kg}(\mathrm{IM}) \text { and ascorbic acid at } 100 \mathrm{mg} / \mathrm{kg}(\mathrm{IV}) \text { and } \\
\text { penicillin } 20,000 \mathrm{IU} / \mathrm{kg} \text { and streptomycin, } 10 \mathrm{mg} / \mathrm{kg}(\mathrm{IM})\end{array}$ \\
B & $\begin{array}{l}\text { Piroxicam at } 5 \mathrm{mg} / \mathrm{kg}(\mathrm{IM}) \text { and ascorbic acid at } 200 \mathrm{mg} / \mathrm{kg}(\mathrm{IV}) \text { and } \\
\text { penicillin } 20,000 \mathrm{IU} / \mathrm{kg} \text { and streptomycin, } 10 \mathrm{mg} / \mathrm{kg}(\mathrm{IM})\end{array}$ \\
C & $\begin{array}{l}\text { Piroxicam at } 10 \mathrm{mg} / \mathrm{kg}(\mathrm{IM}) \text { and ascorbic acid at } 100 \mathrm{mg} / \mathrm{kg}(\mathrm{IV}) \text { and } \\
\text { penicillin } 20,000 \mathrm{IU} / \mathrm{kg} \text { and streptomycin, } 10 \mathrm{mg} / \mathrm{kg}(\mathrm{IM})\end{array}$ \\
D & $\begin{array}{l}\text { Piroxicam at } 5 \mathrm{mg} / \mathrm{kg}(\mathrm{IM}) \text { and penicillin } 20,000 \mathrm{IU} / \mathrm{kg} \text { and } \\
\text { streptomycin, } 10 \mathrm{mg} / \mathrm{kg}(\mathrm{IM})\end{array}$ \\
E & $\begin{array}{l}\text { Ascorbic acid at } 100 \mathrm{mg} / \mathrm{kg}(\mathrm{IV}) \text { and penicillin } 20,000 \mathrm{IU} / \mathrm{kg} \text { and } \\
\text { streptomycin, } 10 \mathrm{mg} / \mathrm{kg}(\mathrm{IM})\end{array}$ \\
F (Control) & penicillin $20,000 \mathrm{IU} / \mathrm{kg}$ and streptomycin, $10 \mathrm{mg} / \mathrm{kg}(\mathrm{IM})$
\end{tabular}

TABLE 2: Percentage (\%) of goats exhibiting signs of back arching after administration of different concentrations of piroxicam, ascorbic acid, and streptomycin/penicillin combination.

\begin{tabular}{|c|c|c|c|c|c|c|}
\hline & Group A & Group B & Group C & Group D & Group E & Group F \\
\hline Baseline & 0 & 0 & 0 & 0 & 0 & 0 \\
\hline Immediately after surgery & 100 & 0 & 0 & 100 & 100 & 100 \\
\hline 3 hours after surgery & 100 & 33.3 & 0 & 100 & 100 & 100 \\
\hline Day 1 & 33.3 & 0 & 33.3 & 100 & 100 & 100 \\
\hline Day 2 & 33.3 & 0 & 33.3 & 100 & 100 & 100 \\
\hline Day 3 & 33.3 & 0 & 0 & 100 & 66.6 & 100 \\
\hline Day 4 & 33.3 & 0 & 0 & 66.6 & 33.3 & 100 \\
\hline Day 5 & 0 & 0 & 0 & 33.3 & 33.3 & 100 \\
\hline
\end{tabular}

Key

$n=3$.

Group A: animals administered with piroxicam at $5 \mathrm{mg} / \mathrm{kg}$ (IM) and ascorbic acid at $100 \mathrm{mg} / \mathrm{kg}$ (IV) and penicillin 20,000 IU $/ \mathrm{kg}$ and streptomycin, $10 \mathrm{mg} / \mathrm{kg}$ (IM).

Group B: animals administered with piroxicam at $5 \mathrm{mg} / \mathrm{kg}$ (IM) and ascorbic acid at $200 \mathrm{mg} / \mathrm{kg}$ (IV) and penicillin 20,000 IU/kg and streptomycin, $10 \mathrm{mg} / \mathrm{kg}$ (IM).

Group C: animals administered with piroxicam at $10 \mathrm{mg} / \mathrm{kg}$ (IM) and ascorbic acid at $100 \mathrm{mg} / \mathrm{kg}$ (IV) and penicillin 20,000 IU/kg and streptomycin, $10 \mathrm{mg} / \mathrm{kg}$ (IM).

Group D: animals administered with piroxicam at $5 \mathrm{mg} / \mathrm{kg}$ (IM) and penicillin 20,000 IU/kg and streptomycin, $10 \mathrm{mg} / \mathrm{kg}$ (IM).

Group E: animals administered with ascorbic acid at $100 \mathrm{mg} / \mathrm{kg}$ (IV) and penicillin 20,000 IU $/ \mathrm{kg}$ and streptomycin, $10 \mathrm{mg} / \mathrm{kg}$ (IM)

Group F (Control): animals administered with penicillin 20,000 IU/kg and streptomycin, $10 \mathrm{mg} / \mathrm{kg}$ (IM).

2.4. Data Analysis. Behavioural response values were summarised in tabular presentations. Data obtained were expressed as simple percentages of the population exhibiting the various signs evaluated.

\section{Results}

Immediately after surgery, no arching of the back was observed in goats in groups $\mathrm{B}$ and $\mathrm{C}$, while all the goats $(100 \%)$ in groups A, D, E, and F exhibited the sign. Three hours later, the sign was observed in $33.3 \%$ of goats in group $\mathrm{B}$ and none in group $\mathrm{C}$ goats, while the sign was observed in all the goats (100\%) in groups A, D, E, and F. From day 1, back arching was no longer observed in group A goats, while $33.3 \%$ of goats in groups A and C, $100 \%$ of groups D, E, and F exhibited the sign of back arching. All goats in group F (100\%) exhibited the sign till the end of the study (Table 2).

No vocalisation was recorded in groups A and B throughout the experiment. $33.3 \%$ of goats exhibited the sign in groups $\mathrm{C}$ and $\mathrm{D}$ immediately after surgery and three hours after surgery in group E. 66.6\% of the goats in group F exhibited the sign three hours after surgery, and the percentage increased to $100 \%$ on days 1 and 2 but gradually reduced to 0 on day 5 (Table 3 ).

Teeth grinding was not recorded in group C goats throughout the experiment and immediately after surgery and on days 4 and 5 in group B. $66.6 \%$ of the goats manifested the sign in groups A (immediately after surgery and day 3) and D (day 3), while $33.3 \%$ showed the sign in group E immediately after surgery till day 3 , and none on days 4 and 5 . However, $66.6 \%$ of group F goats exhibited the sign immediately after surgery, which increased to $100 \%$ three hours later till day 4 , while, on day $5,66.6 \%$ exhibited the sign (Table 4).

All the goats (100\%) in group A expressed rapid shallow breathing immediately after surgery till day 5 , when only $66.6 \%$ of the population had the breathing. Group B recorded the same till day 1 and then to $66.6 \%$ on day 2 , and none 
TABLE 3: Percentage (\%) of goats exhibiting sign of vocalisation after administration of different concentrations of piroxicam, ascorbic acid, and streptomycin/penicillin combination.

\begin{tabular}{|c|c|c|c|c|c|c|}
\hline & Group A & Group B & Group C & Group D & Group E & Group F \\
\hline Baseline & 0 & 0 & 0 & 0 & 0 & 0 \\
\hline Immediately after surgery & 0 & 0 & 33.3 & 33.3 & 0 & 0 \\
\hline 3 hours after surgery & 0 & 0 & 0 & 100 & 33.3 & 66.6 \\
\hline Day 1 & 0 & 0 & 0 & 66.6 & 0 & 100 \\
\hline Day 2 & 0 & 0 & 0 & 0 & 0 & 100 \\
\hline Day 3 & 0 & 0 & 0 & 0 & 0 & 66.6 \\
\hline Day 4 & 0 & 0 & 0 & 0 & 0 & 33.3 \\
\hline Day 5 & 0 & 0 & 0 & 0 & 0 & 0 \\
\hline
\end{tabular}

Key

$n=3$.

Group A: animals administered with piroxicam at $5 \mathrm{mg} / \mathrm{kg}$ (IM) and ascorbic acid at $100 \mathrm{mg} / \mathrm{kg}$ (IV) and penicillin 20,000 IU $/ \mathrm{kg}$ and streptomycin, $10 \mathrm{mg} / \mathrm{kg}$ (IM).

Group B: animals administered with piroxicam at $5 \mathrm{mg} / \mathrm{kg}$ (IM) and ascorbic acid at $200 \mathrm{mg} / \mathrm{kg}$ (IV) and penicillin 20,000 IU/kg and streptomycin, $10 \mathrm{mg} / \mathrm{kg}$ (IM).

Group C: animals administered with piroxicam at $10 \mathrm{mg} / \mathrm{kg}$ (IM) and ascorbic acid at $100 \mathrm{mg} / \mathrm{kg}$ (IV) and penicillin 20,000 IU/kg and streptomycin, $10 \mathrm{mg} / \mathrm{kg}$ (IM).

Group D: animals administered with piroxicam at $5 \mathrm{mg} / \mathrm{kg}$ (IM) and penicillin 20,000 IU/kg and streptomycin, $10 \mathrm{mg} / \mathrm{kg}$ (IM).

Group E: animals administered with ascorbic acid at $100 \mathrm{mg} / \mathrm{kg}$ (IV) and penicillin 20,000 IU $/ \mathrm{kg}$ and streptomycin, $10 \mathrm{mg} / \mathrm{kg}$ (IM).

Group F (Control): animals administered with penicillin 20,000 IU/kg and streptomycin, $10 \mathrm{mg} / \mathrm{kg}$ (IM).

TABLe 4: Percentage (\%) of goats exhibiting signs of teeth grinding after administration of different concentrations of piroxicam, ascorbic acid, and streptomycin/penicillin combination.

\begin{tabular}{|c|c|c|c|c|c|c|}
\hline & Group A & Group B & Group C & Group D & Group E & Group F \\
\hline Baseline & 0 & 0 & 0 & 0 & 0 & 0 \\
\hline Immediately after surgery & 66.6 & 0 & 0 & 100 & 33.3 & 66.6 \\
\hline 3 hours after surgery & 100 & 100 & 0 & 100 & 33.3 & 100 \\
\hline Day 1 & 100 & 33.3 & 0 & 100 & 33.3 & 100 \\
\hline Day 2 & 100 & 33.3 & 0 & 33.3 & 33.3 & 100 \\
\hline Day 3 & 66.6 & 33.3 & 0 & 66.6 & 33.3 & 100 \\
\hline Day 4 & 0 & 0 & 0 & 33.3 & 0 & 100 \\
\hline Day 5 & 0 & 0 & 0 & 0 & 0 & 66.6 \\
\hline
\end{tabular}

Key

$n=3$.

Group A: animals administered with piroxicam at $5 \mathrm{mg} / \mathrm{kg}$ (IM) and ascorbic acid at $100 \mathrm{mg} / \mathrm{kg}$ (IV) and penicillin 20,000 IU $/ \mathrm{kg}$ and streptomycin, $10 \mathrm{mg} / \mathrm{kg}$ (IM).

Group B: animals administered with piroxicam at $5 \mathrm{mg} / \mathrm{kg}$ (IM) and ascorbic acid at $200 \mathrm{mg} / \mathrm{kg}$ (IV) and penicillin 20,000 IU $/ \mathrm{kg}$ and streptomycin, $10 \mathrm{mg} / \mathrm{kg}$ (IM).

Group C: animals administered with piroxicam at $10 \mathrm{mg} / \mathrm{kg}$ (IM) and ascorbic acid at $100 \mathrm{mg} / \mathrm{kg}$ (IV) and penicillin 20,000 IU $/ \mathrm{kg}$ and streptomycin, $10 \mathrm{mg} / \mathrm{kg}$ (IM).

Group D: animals administered with piroxicam at $5 \mathrm{mg} / \mathrm{kg}$ (IM) and penicillin 20,000 IU/kg and streptomycin, $10 \mathrm{mg} / \mathrm{kg}$ (IM).

Group E: animals administered with ascorbic acid at $100 \mathrm{mg} / \mathrm{kg}$ (IV) and penicillin 20,000 IU/ $\mathrm{kg}$ and streptomycin, $10 \mathrm{mg} / \mathrm{kg}$ (IM).

Group F (Control): animals administered with penicillin 20,000 IU/kg and streptomycin, $10 \mathrm{mg} / \mathrm{kg}$ (IM).

thereafter. The lowest percentage population expression was observed in group C immediately after surgery and on days 3 and 5 in group E, while those in the control group exhibited the sign throughout the experimental period (Table 5).

Bleating was not recorded in goats of groups A and B throughout the study period; $33.3 \%$ recorded the sign three hours after surgery in group E, and $66.6 \%$ in group C. All the goats in the control group recorded the sign three hours and up till day 3 after surgery, while only $33.3 \%$ of the control group exhibited the sign on days 4 and 5 (Table 6). The sign of tail wagging was not exhibited by group B goats, but groups $\mathrm{A}$ and $\mathrm{C}$ showed a gradual decrease in numbers of goats exhibiting the sign from day 1 . However, all the goats of group F showed sign of tail wagging throughout the experimental period (Table 7). Neck extension was not observed in goats in groups $\mathrm{A}, \mathrm{B}$, and $\mathrm{C}$ from day 2 . The lowest percentage of goats (33.3\%) exhibiting the sign of neck extension was observed in group $\mathrm{C}$ immediately after surgery, and in group $\mathrm{E}$ on day 5. The control goats showed the highest percentage (100\%) from three hours after surgery till the end of the experiment (Table 8).

Dorsal lip curling was not observed from day 2 in group B, and from day 3 in group C goats (Table 9); $33.3 \%$ of goats manifested the sign in group A from day 2, and on day 4 in 
TABLE 5: Percentage (\%) of goats exhibiting signs of rapid shallow breathing after administration of different concentrations of piroxicam, ascorbic acid, and streptomycin/penicillin combination.

\begin{tabular}{|c|c|c|c|c|c|c|}
\hline & Group A & Group B & Group C & Group D & Group E & Group F \\
\hline Baseline & 0 & 0 & 0 & 0 & 0 & 0 \\
\hline Immediately after surgery & 100 & 100 & 33.3 & 100 & 100 & 66.6 \\
\hline 3 hours after surgery & 100 & 100 & 100 & 66.6 & 100 & 100 \\
\hline Day 1 & 100 & 100 & 100 & 100 & 100 & 100 \\
\hline Day 2 & 100 & 66.6 & 100 & 100 & 100 & 100 \\
\hline Day 3 & 100 & 0 & 33.3 & 100 & 100 & 100 \\
\hline Day 4 & 100 & 0 & 0 & 100 & 66.6 & 100 \\
\hline Day 5 & 66.6 & 0 & 0 & 66.6 & 33.3 & 100 \\
\hline
\end{tabular}

Key

$n=3$.

Group A: animals administered with piroxicam at $5 \mathrm{mg} / \mathrm{kg}$ (IM) and ascorbic acid at $100 \mathrm{mg} / \mathrm{kg}$ (IV) and penicillin 20,000 IU/kg and streptomycin, $10 \mathrm{mg} / \mathrm{kg}$ (IM).

Group B: animals administered with piroxicam at $5 \mathrm{mg} / \mathrm{kg}$ (IM) and ascorbic acid at $200 \mathrm{mg} / \mathrm{kg}$ (IV) and penicillin 20,000 IU $/ \mathrm{kg}$ and streptomycin, $10 \mathrm{mg} / \mathrm{kg}$ (IM).

Group C: animals administered with piroxicam at $10 \mathrm{mg} / \mathrm{kg}$ (IM) and ascorbic acid at $100 \mathrm{mg} / \mathrm{kg}$ (IV) and penicillin 20,000 IU/kg and streptomycin, $10 \mathrm{mg} / \mathrm{kg}$ (IM).

Group D: animals administered with piroxicam at $5 \mathrm{mg} / \mathrm{kg}$ (IM) and penicillin 20,000 IU/kg and streptomycin, $10 \mathrm{mg} / \mathrm{kg}$ (IM).

Group E: animals administered with ascorbic acid at $100 \mathrm{mg} / \mathrm{kg}$ (IV) and penicillin 20,000 IU $/ \mathrm{kg}$ and streptomycin, $10 \mathrm{mg} / \mathrm{kg}$ (IM).

Group F (Control): animals administered with penicillin 20,000 IU/kg and streptomycin, $10 \mathrm{mg} / \mathrm{kg}$ (IM).

TABLE 6: Percentage (\%) of goats exhibiting signs of bleating after administration of different concentrations of piroxicam, ascorbic acid, and streptomycin/penicillin combination.

\begin{tabular}{|c|c|c|c|c|c|c|}
\hline & Group A & Group B & Group C & Group D & Group E & Group F \\
\hline Baseline & 0 & 0 & 0 & 0 & 0 & 0 \\
\hline Immediately after surgery & 0 & 0 & 0 & 33.3 & 0 & 66.6 \\
\hline 3 hours after surgery & 0 & 0 & 66.6 & 66.6 & 33.3 & 100 \\
\hline Day 1 & 0 & 0 & 0 & 33.3 & 0 & 100 \\
\hline Day 2 & 0 & 0 & 0 & 0 & 0 & 100 \\
\hline Day 3 & 0 & 0 & 0 & 0 & 0 & 100 \\
\hline Day 4 & 0 & 0 & 0 & 0 & 0 & 33.3 \\
\hline Day 5 & 0 & 0 & 0 & 0 & 0 & 33.3 \\
\hline
\end{tabular}

Key

$n=3$.

Group A: animals administered with piroxicam at $5 \mathrm{mg} / \mathrm{kg}$ (IM) and ascorbic acid at $100 \mathrm{mg} / \mathrm{kg}$ (IV) and penicillin 20,000 IU $/ \mathrm{kg}$ and streptomycin, $10 \mathrm{mg} / \mathrm{kg}$ (IM).

Group B: animals administered with piroxicam at $5 \mathrm{mg} / \mathrm{kg}$ (IM) and ascorbic acid at $200 \mathrm{mg} / \mathrm{kg}$ (IV) and penicillin 20,000 IU $/ \mathrm{kg}$ and streptomycin, $10 \mathrm{mg} / \mathrm{kg}$ (IM).

Group C: animals administered with piroxicam at $10 \mathrm{mg} / \mathrm{kg}$ (IM) and ascorbic acid at $100 \mathrm{mg} / \mathrm{kg}$ (IV) and penicillin 20,000 IU/kg and streptomycin, $10 \mathrm{mg} / \mathrm{kg}$ (IM).

Group D: animals administered with piroxicam at $5 \mathrm{mg} / \mathrm{kg}$ (IM) and penicillin 20,000 IU/kg and streptomycin, $10 \mathrm{mg} / \mathrm{kg}$ (IM).

Group E: animals administered with ascorbic acid at $100 \mathrm{mg} / \mathrm{kg}$ (IV) and penicillin 20,000 IU $/ \mathrm{kg}$ and streptomycin, $10 \mathrm{mg} / \mathrm{kg}$ (IM).

Group F (Control): animals administered with penicillin 20,000 IU/kg and streptomycin, $10 \mathrm{mg} / \mathrm{kg}$ (IM).

group D. The percentages decreased from $100 \%$ in goats in groups D and $\mathrm{E}$ while those of the control goats increased till the end of the experiment.

The behavioural signs investigated gradually disappeared in goats belonging to groups $\mathrm{B}, \mathrm{C}, \mathrm{A}, \mathrm{E}, \mathrm{D}$, and F, respectively. The signs which showed more severity were rapid shallow breathing, neck extension, dorsal lip curling, and tail wagging.

\section{Discussion}

Behavioural signs of pain observed in this study were vocalisation, teeth grinding, rapid and shallow breathing, tail wagging, occasionally bleating, neck extension, and dorsal lip curling and the observations agree with the report of Wendy [7] and NAS [8]. However, kicking, rolling, standing, and lying down were not exhibited across the experimental groups as reported by NAS [8]. This finding may be due to the sedative effect of xylazine that was used together with the anaesthetic effect of lignocaine hydrochloride in the present study. It may also be due to the fact that the orchidectomy carried out may not elicit acute but rather subacute pain. The result also demonstrated the efficacy of multimodal approach to postsurgical pain management, as goats in group $\mathrm{B}$ (piroxicam at $5 \mathrm{mg} / \mathrm{kg}$ (IM) and ascorbic acid at $200 \mathrm{mg} / \mathrm{kg}$ (IV) and penicillin 20,000 IU/kg, and streptomycin, $10 \mathrm{mg} / \mathrm{kg}$ 
TABLE 7: Percentage (\%) of goats exhibiting signs of tail wagging after administration of different concentrations of piroxicam, ascorbic acid, and streptomycin/penicillin combination.

\begin{tabular}{|c|c|c|c|c|c|c|}
\hline & Group A & Group B & Group C & Group D & Group E & Group F \\
\hline Baseline & 0 & 0 & 0 & 0 & 0 & 0 \\
\hline Immediately after surgery & 66.6 & 0 & 0 & 100 & 66.6 & 100 \\
\hline 3 hours after surgery & 100 & 0 & 100 & 100 & 100 & 100 \\
\hline Day 1 & 66.6 & 0 & 66.6 & 100 & 100 & 100 \\
\hline Day 2 & 66.6 & 0 & 33.3 & 100 & 100 & 100 \\
\hline Day 3 & 33.3 & 0 & 33.3 & 100 & 100 & 100 \\
\hline Day 4 & 33.3 & 0 & 33.3 & 66.6 & 100 & 100 \\
\hline Day 5 & 0 & 0 & 0 & 66.6 & 33.3 & 100 \\
\hline
\end{tabular}

Key

$n=3$.

Group A: animals administered with piroxicam at $5 \mathrm{mg} / \mathrm{kg}$ (IM) and ascorbic acid at $100 \mathrm{mg} / \mathrm{kg}$ (IV) and penicillin 20,000 IU $/ \mathrm{kg}$ and streptomycin, $10 \mathrm{mg} / \mathrm{kg}$ (IM).

Group B: animals administered with piroxicam at $5 \mathrm{mg} / \mathrm{kg}$ (IM) and ascorbic acid at $200 \mathrm{mg} / \mathrm{kg}$ (IV) and penicillin $20,000 \mathrm{IU} / \mathrm{kg}$ and streptomycin, $10 \mathrm{mg} / \mathrm{kg}$ (IM).

Group C: animals administered with piroxicam at $10 \mathrm{mg} / \mathrm{kg}$ (IM) and ascorbic acid at $100 \mathrm{mg} / \mathrm{kg}$ (IV) and penicillin 20,000 IU/kg and streptomycin, $10 \mathrm{mg} / \mathrm{kg}$ (IM).

Group D: animals administered with piroxicam at $5 \mathrm{mg} / \mathrm{kg}$ (IM) and penicillin 20,000 IU/kg and streptomycin, $10 \mathrm{mg} / \mathrm{kg}$ (IM).

Group E: animals administered with ascorbic acid at $100 \mathrm{mg} / \mathrm{kg}$ (IV) and penicillin 20,000 IU $/ \mathrm{kg}$ and streptomycin, $10 \mathrm{mg} / \mathrm{kg}$ (IM).

Group F (Control): animals administered with penicillin 20,000 IU/kg and streptomycin, $10 \mathrm{mg} / \mathrm{kg}$ (IM).

TABLE 8: Percentage (\%) of goats exhibiting signs of neck extension after administration of different concentrations of piroxicam, ascorbic acid, and streptomycin/penicillin combination.

\begin{tabular}{|c|c|c|c|c|c|c|}
\hline & Group A & Group B & Group C & Group D & Group E & Group F \\
\hline Baseline & 0 & 0 & 0 & 0 & 0 & 0 \\
\hline Immediately after surgery & 100 & 100 & 33.3 & 100 & 66.6 & 66.6 \\
\hline 3 hours after surgery & 100 & 66.6 & 100 & 66.6 & 100 & 100 \\
\hline Day 1 & 66.6 & 66.6 & 100 & 100 & 100 & 100 \\
\hline Day 2 & 0 & 0 & 0 & 100 & 100 & 100 \\
\hline Day 3 & 0 & 0 & 0 & 100 & 100 & 100 \\
\hline Day 4 & 0 & 0 & 0 & 66.6 & 66.6 & 100 \\
\hline Day 5 & 0 & 0 & 0 & 66.6 & 33.3 & 100 \\
\hline
\end{tabular}

Key

$n=3$.

Group A: animals administered with piroxicam at $5 \mathrm{mg} / \mathrm{kg}$ (IM) and ascorbic acid at $100 \mathrm{mg} / \mathrm{kg}$ (IV) and penicillin 20,000 IU/kg and streptomycin, $10 \mathrm{mg} / \mathrm{kg}$ (IM).

Group B: animals administered with piroxicam at $5 \mathrm{mg} / \mathrm{kg}$ (IM) and ascorbic acid at $200 \mathrm{mg} / \mathrm{kg}$ (IV) and penicillin 20,000 IU/kg and streptomycin, $10 \mathrm{mg} / \mathrm{kg}$ (IM).

Group C: animals administered with piroxicam at $10 \mathrm{mg} / \mathrm{kg}$ (IM) and ascorbic acid at $100 \mathrm{mg} / \mathrm{kg}$ (IV) and penicillin 20,000 IU/kg and streptomycin, $10 \mathrm{mg} / \mathrm{kg}$ (IM).

Group D: animals administered with piroxicam at $5 \mathrm{mg} / \mathrm{kg}$ (IM) and penicillin 20,000 IU/kg and streptomycin, $10 \mathrm{mg} / \mathrm{kg}$ (IM).

Group E: animals administered with ascorbic acid at $100 \mathrm{mg} / \mathrm{kg}$ (IV), penicillin 20,000 IU/kg and streptomycin, $10 \mathrm{mg} / \mathrm{kg}$ (IM)

Group F (Control): animals administered with penicillin 20,000 IU/kg and streptomycin, $10 \mathrm{mg} / \mathrm{kg}$ (IM).

(IM)) followed by those in group A (piroxicam at $5 \mathrm{mg} / \mathrm{kg}$ (IM) and ascorbic acid at $100 \mathrm{mg} / \mathrm{kg}$ (IV) and penicillin $20,000 \mathrm{IU} / \mathrm{kg}$ and streptomycin, $10 \mathrm{mg} / \mathrm{kg}$ (IM)), and those in group $\mathrm{C}$ (with piroxicam at $10 \mathrm{mg} / \mathrm{kg}$ (IM) and ascorbic acid at $100 \mathrm{mg} / \mathrm{kg}$ (IV) and penicillin 20,000 IU/kg and streptomycin, $10 \mathrm{mg} / \mathrm{kg}$ (IM)), respectively, showed a greater response to treatment by exhibiting lower rating scores for signs of behavioural pain. The study showed that ascorbic acid may ameliorate behavioural signs of postsurgical pain more than piroxicam. This finding agrees with some studies, which have shown that ascorbic acid exerted ameliorative effects on stressful environmental conditions[16-19] by scavenging reactive oxygen species generation [14].

It is concluded that multimodal approach to surgical pain management is the best option and that piroxicam and ascorbic acid combination is very effective in the management of postsurgical pain, at the dose rate of $5 \mathrm{mg} / \mathrm{kg}$ IM and $200 \mathrm{mg} / \mathrm{kg} \mathrm{IV}$, respectively. It is recommended that a combination of piroxicam and ascorbic acid be administered in order to ameliorate behavioral signs of pain. 
TABLE 9: Percentage (\%) of goats exhibiting signs of dorsal lip curling after administration of different concentrations of piroxicam, ascorbic acid, and streptomycin/penicillin combination.

\begin{tabular}{|c|c|c|c|c|c|c|}
\hline & Group A & Group B & Group C & Group D & Group E & Group F \\
\hline Baseline & 0 & 0 & 0 & 0 & 0 & 0 \\
\hline Immediately after surgery & 66.6 & 0 & 33.3 & 100 & 100 & 66.6 \\
\hline 3 hours after surgery & 100 & 100 & 66.6 & 100 & 100 & 100 \\
\hline Day 1 & 100 & 100 & 66.6 & 100 & 100 & 100 \\
\hline Day 2 & 33.3 & 0 & 33.3 & 100 & 100 & 100 \\
\hline Day 3 & 33.3 & 0 & 0 & 100 & 100 & 100 \\
\hline Day 4 & 33.3 & 0 & 0 & 33.3 & 100 & 100 \\
\hline Day 5 & 33.3 & 0 & 0 & 66.6 & 0 & 100 \\
\hline
\end{tabular}

Key

$n=3$.

Group A: animals administered with piroxicam at $5 \mathrm{mg} / \mathrm{kg}$ (IM) and ascorbic acid at $100 \mathrm{mg} / \mathrm{kg}$ (IV) and penicillin $20,000 \mathrm{IU} / \mathrm{kg}$ and streptomycin, $10 \mathrm{mg} / \mathrm{kg}$ (IM).

Group B: animals administered with piroxicam at $5 \mathrm{mg} / \mathrm{kg}$ (IM) and ascorbic acid at $200 \mathrm{mg} / \mathrm{kg}$ (IV) and penicillin 20,000 IU $/ \mathrm{kg}$ and streptomycin, $10 \mathrm{mg} / \mathrm{kg}$ (IM).

Group C: animals administered with piroxicam at $10 \mathrm{mg} / \mathrm{kg}$ (IM) and ascorbic acid at $100 \mathrm{mg} / \mathrm{kg}$ (IV) and penicillin 20,000 IU/kg and streptomycin, $10 \mathrm{mg} / \mathrm{kg}$ (IM).

Group D: animals administered with piroxicam at $5 \mathrm{mg} / \mathrm{kg}$ (IM) and penicillin 20,000 IU/kg and streptomycin, $10 \mathrm{mg} / \mathrm{kg}$ (IM).

Group E: animals administered with ascorbic acid at $100 \mathrm{mg} / \mathrm{kg}$ (IV) and penicillin 20,000 IU/kg and streptomycin, $10 \mathrm{mg} / \mathrm{kg}$ (IM)

Group F (Control): animals administered with penicillin 20,000 IU/kg and streptomycin, $10 \mathrm{mg} / \mathrm{kg}$ (IM).

\section{Conflict of Interests}

The authors declare that there is no conflict of interests regarding the publication of this paper.

\section{References}

[1] A. C. D. Bayvel, "OIE animal welfare strategic initiative: progress, priorities and prognosis," in Proceedings of the Global Conference on Animal Welfare: An OIE Initiative, World Organization for Animal Health, Paris, France, 2004.

[2] S. L. Wright-Williams, J.-P. Courade, C. A. Richardson, J. V. Roughan, and P. A. Flecknell, "Effects of vasectomy surgery and meloxicam treatment on faecal corticosterone levels and behaviour in two strains of laboratory mouse," Pain, vol. 130, no. 1-2, pp. 108-118, 2007.

[3] E. Hunton, A. Ascher, and M. Tokiwa, "Animal Welfare Task Force: Guidelines for Preventing, Recognizing, and Treating Pain in the Hospital Setting and Guidelines for Pet Owners for Recognizing Pain in their Dogs and Cats," New Jersey Veterinary Medical Association, 2005.

[4] D. M. Weary, L. Niel, F. C. Flower, and D. Fraser, "Identifying and preventing pain in animals," Applied Animal Behaviour Science, vol. 100, no. 1-2, pp. 64-76, 2006.

[5] D. B. Morton and P. H. Griffiths, "Guidelines on the recognition of pain, distress and discomfort in experimental animals and an hypothesis for assessment." Veterinary Record, vol. 116, no. 16, pp. 431-436, 1985.

[6] J. N. Marchant-Forde, D. C. Lay Jr., K. A. McMunn, H. W. Cheng, E. A. Pajor, and R. M. Marchant-Forde, "Postnatal piglet husbandry practices and well-being: the effects of alternative techniques delivered separately," Journal of Animal Science, vol. 87, no. 4, pp. 1479-1492, 2009.

[7] J. U. Wendy, "Animal welfare forum: pain management," Journal of American Veterinary Medical Association, vol. 221, no. 2, p. 2, 2002.
[8] National Academy of Sciences (NAS), "Recognition and Alleviation of Pain in Laboratory Animals," National Research Council, Committee on Recognition and Alleviation of Pain in Laboratory Animals, 2009.

[9] M. McCaffery and C. Pasero, Pain: Clinical Manual, Mosby, St. Louis, Mo, USA, 1999.

[10] P. Agrawal and A. Gupta, "Non steroidal anti inflammatory drugs," 2010, http://en.engormix.com/MA-dairy-cattle/dairyindustry/articles/nsaids-t1498/p0.htm.

[11] T. Hedner, O. Samulesson, P. Wahrborg, H. Wadenvik, K. A. Ung, and A. Ekbom, "Therapeutic use and safety profile in the management of osteoarthritis's and rheumatoid arthritis," Drugs, vol. 64, no. 20, pp. 2315-2343, 2004.

[12] S. Izdes, S. Orhun, S. Turanli, E. Erkilic, and O. Kanbak, "The effects of preoperative inflammation on the analgesic efficacy of intraarticular piroxicam for outpatient knee arthroscopy," Anesthesia and Analgesia, vol. 97, no. 4, pp. 1016-1019, 2003.

[13] M. H. Abdallah, A. Omaima, H. A. Sammour, E. L. Ghamry, and E. A. Mohammed, "Design and development of piroxicamentrapped niosomes as an oral drug delivery system," International Journal of Advances in Pharmaceutical Research, 2013.

[14] S. K. Powers and M. J. Jackson, "Exercise-induced oxidative stress: cellular mechanisms and impact on muscle force production," Physiological Reviews, vol. 88, no. 4, pp. 1243-1276, 2008.

[15] W. Dröge, "Free radicals in the physiological control of cell function," Physiological Reviews, vol. 82, no. 1, pp. 47-95, 2002.

[16] C. C. Whitehead and T. Keller, "An update on ascorbic acid in poultry," World's Poultry Science Journal, vol. 59, no. 2, pp. 161184, 2003.

[17] P. Tauler, A. Aguiló, I. Gimeno, E. Fuentespina, J. A. Tur, and A. Pons, "Influence of vitamin $\mathrm{C}$ diet supplementation on endogenous antioxidant defences during exhaustive exercise," Pflugers Archiv European Journal of Physiology, vol. 446, no. 6, pp. 658-664, 2003.

[18] A. Y. Adenkola and J. O. Ayo, "Effect of ascorbic acid on diurnal variations in rectal temperature of local turkey growers during 
the hot-dry season," in Proceedings of the 11th Annual Conference of Animal Science Association of Nigeria, pp. 13-15, Ibadan, Nigeria, September 2006.

[19] A. Y. Adenkola and J. O. Ayo, "Effect of ascorbic acid on diurnal variations in rectal temperature of piglets during the harmattan season," in Proceedings of the 11th Annual conference of Animal Science Association of Nigeria, pp. 9-12, Ibadan, Nigeria, 2006.

[20] N. S. Minka and J. O. Ayo, "Physiological responses of transported goats treated with ascorbic acid during the hot-dry season," Animal Science Journal, vol. 78, no. 2, pp. 164-172, 2007.

[21] I. U. Yarube, M. A.-H. Mohammad, J. O. Ayo, and K. V. Olorunshola, "Antioxidant vitamins $\mathrm{C}$ and $\mathrm{E}$ alleviate the toxicity induced by chronic sodium nitrate administration on sperm count and serum testosterone level in Wistar rats," European Journal of Scientific Research, vol. 25, no. 1, pp. 35-41, 2009.

[22] S. T. Fadason, S. Joshua, B. D. Remi-Adewunmi, A. K. B. Sackey, Z. A. Hassan, and C. A. Awasum, "Common surgical procedures in the Ahmadu Bello University Veterinary Teaching Hospital (ABUVTH), Zaria between 2001-2005," in Proceedings of the 44th Annual Congress Nigerian Veterinary Medical Association, Shell Block Conference Centre, Petroleum Training Institute, Effurum, pp. 69-71, Delta State, Nigeria, October 2007.

[23] B. D. Remi-Adewunmi and E. O. Gyang, "Development of pain recognition and management protocol for veterinary practice," in Proceedings of the 47th Annual Congress of Nigerian Veterinary Medical Association (NVMA '10), Auditorium, College Of Health Sciences, Benue State University, Makurdi-Benue State, Nigeria, October 2010.

[24] AVMA, "Welfare implications of castration of cattle," 2006, https://www.avma.org/KB/Resources/LiteratureReviews/Pages/ castration-cattle-bgnd.aspx.

[25] CVMA, "Animal welfare position statements: castration, tail docking, dehorning of farm animals," 2011, http://www.canadianveterinarians.net/ShowText.aspx?ResourceID=1935.

[26] A. Prunier, A. M. Mounier, and M. Hay, "Effects of castration, tooth resection, or tail docking on plasma metabolites and stress hormones in young pigs," Journal of Animal Science, vol. 83, no. 1, pp. 216-222, 2005.

[27] S. L. Fubini and N. G. Ducharme, "Surgery of the male reproductive tract: castration," in Food Animal Surgery, pp. 578582, Saunders, 2004.

[28] A. T. Simon and C. M. Wayne, "Bovine urogenital surgery: castration," in Techniques in Large Animal Surger, pp. 250-253, Lea and Febiger, Philadelphia, Pa, USA, 1992.

[29] D. E. Bourne and B. A. Forbes, "Ruminants Pain Management/Techniques and protocols Overview," 2005, http://wildpro.twycrosszoo.org/S/00Ref/KeywordsContents/n/Numerical_rating_scale.htm. 

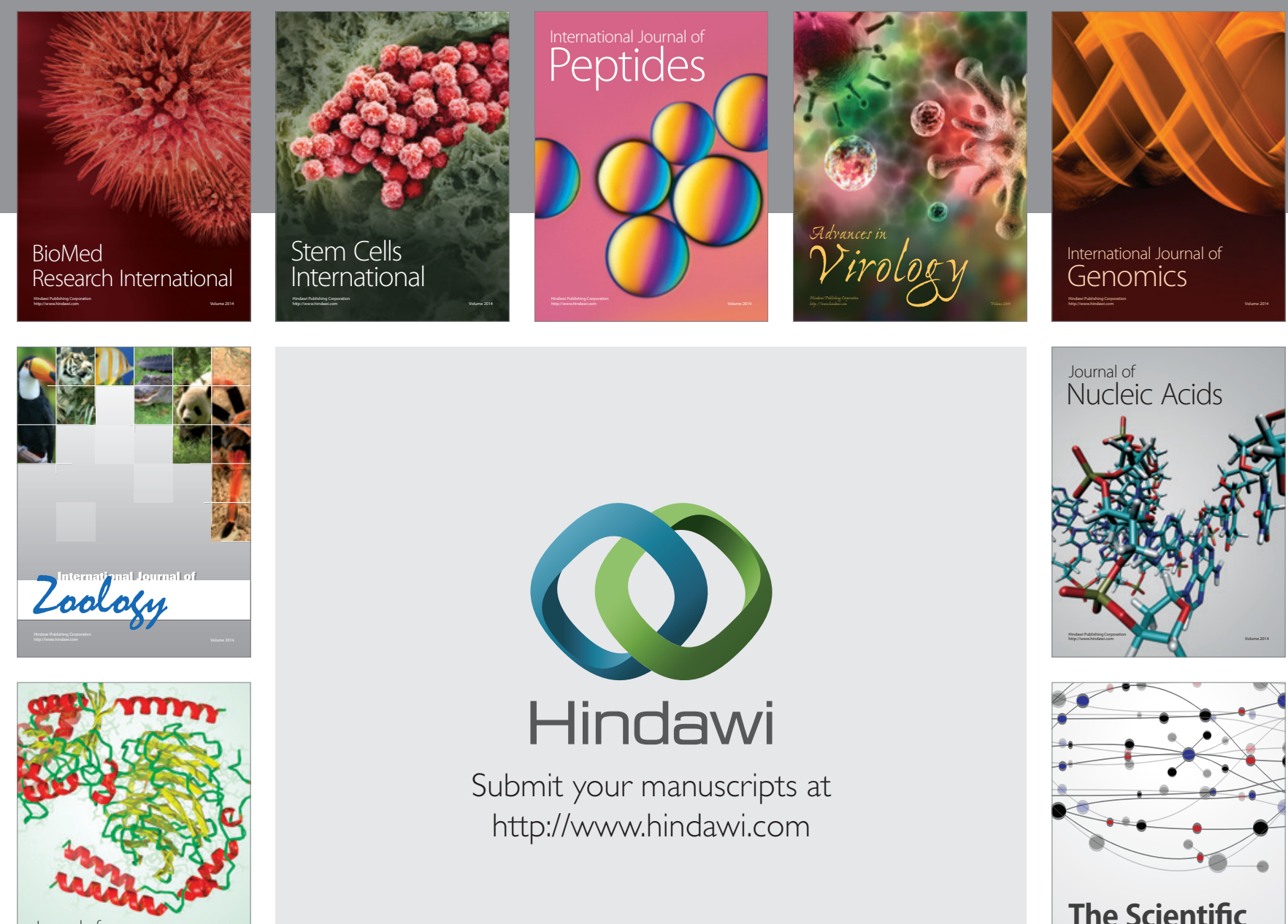

Submit your manuscripts at

http://www.hindawi.com

Journal of
Signal Transduction
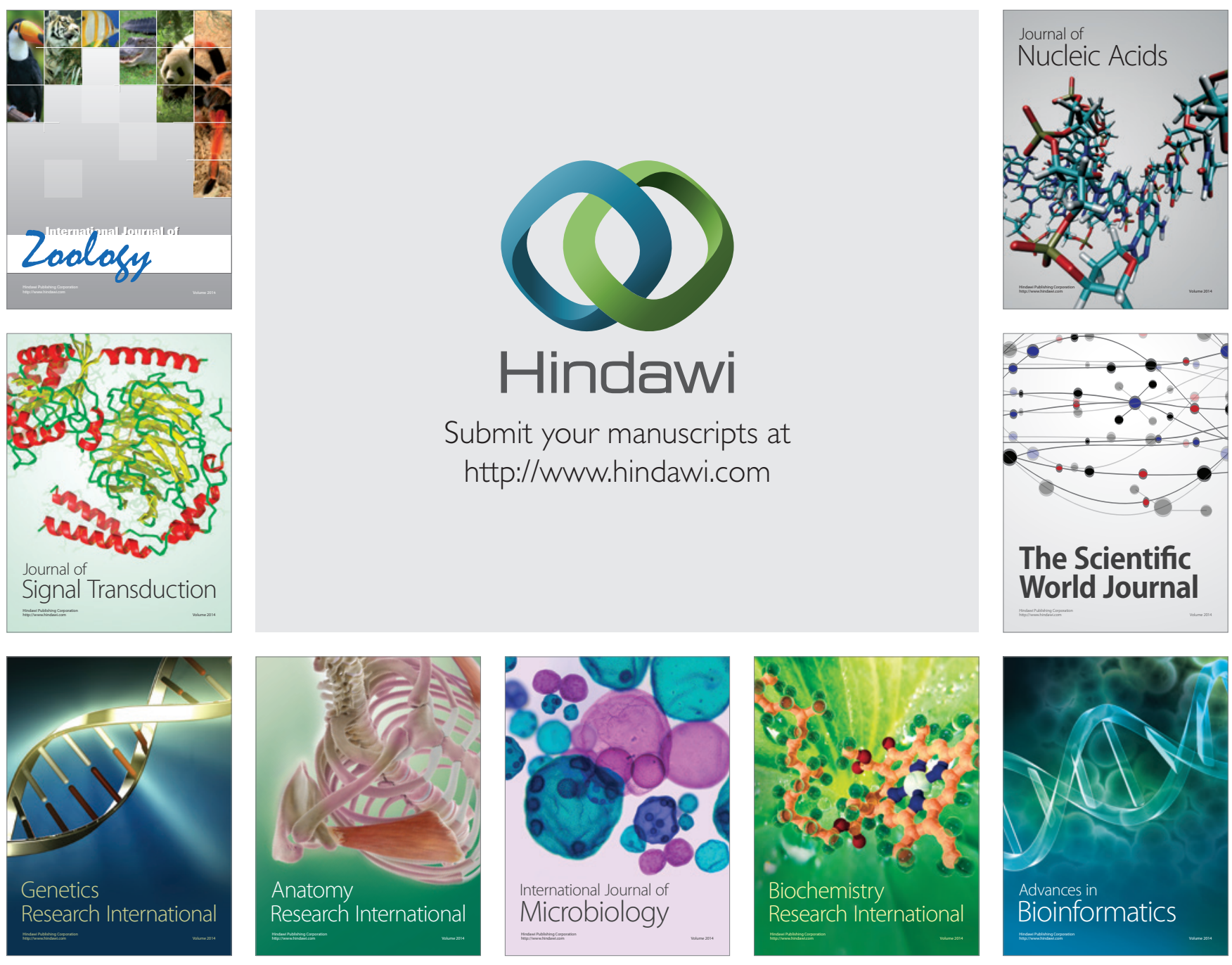

The Scientific World Journal
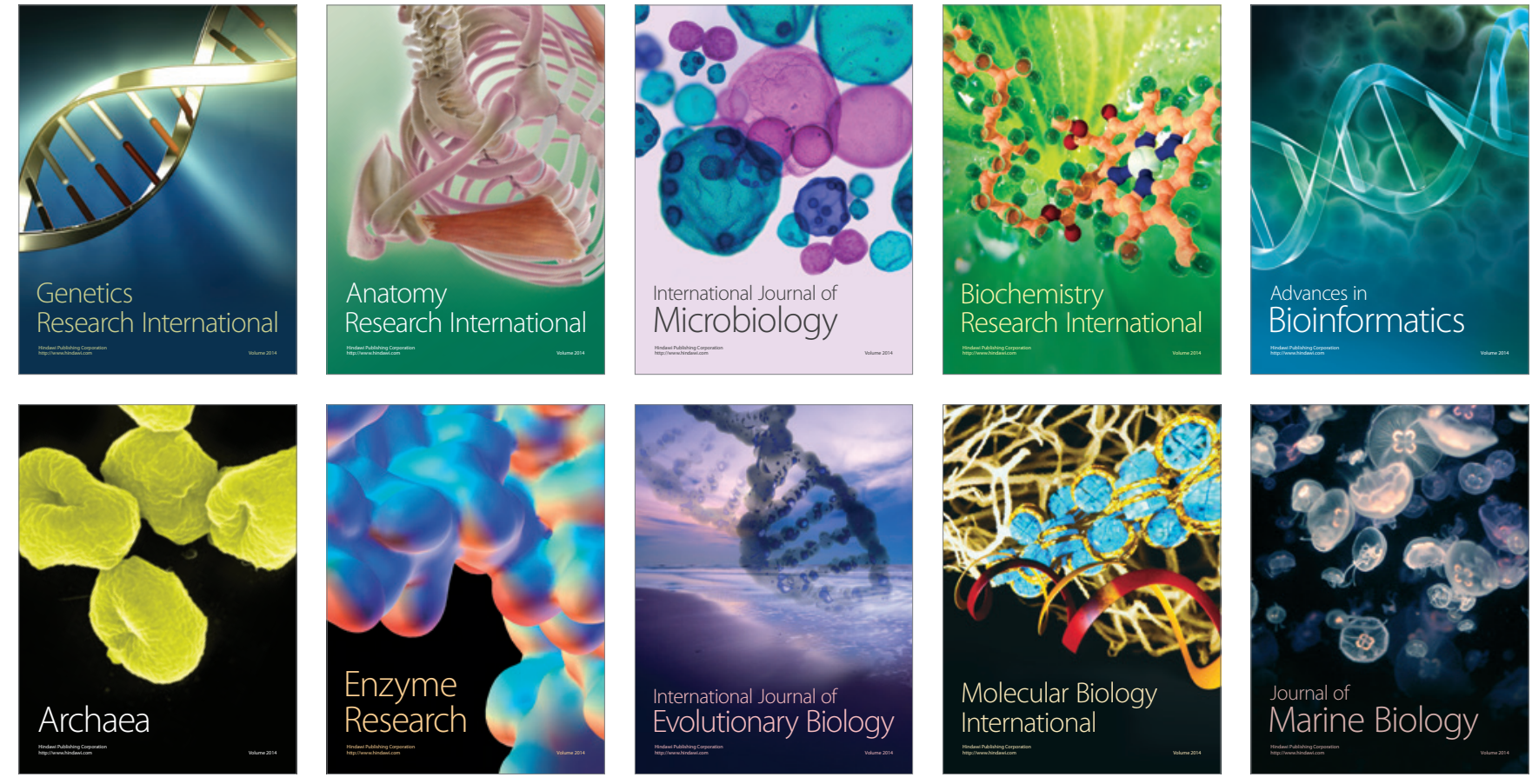